\title{
PENGARUH STRUKTUR MODAL DAN LIKUIDITAS TERHADAP KINERJA KEUANGAN PADA PERUSAHAAN PERBANKAN YANG TERDAFTAR DI BEI PERIODE 2014-2018 Febransyah $^{1}$, Titi Suelmi ${ }^{2}$
}

\author{
1. Dosen jurusan Akuntansi, Universitas Tridinanti, Sumatera Selatan \\ 2, Dosen jurusan Akuntansi, Universitas Tridinanti, Sumatera Selatan \\ 1)Email : febransyah@univ-tridinanti.ac.id
}

\section{Submitted: \\ $14 / 11 / 2021$ \\ Revised: \\ $20 / 11 / 2021$ \\ Accepted: \\ $25 / 12 / 2021$ \\ Online-Published: \\ $30 / 12 / 2021$}

INFORMASI ARTIKEL

\begin{abstract}
ABSTRAK
Penelitian ini bertujuan untuk memperoleh bukti empiris tentang: (1) Pengaruh Struktur Modal Terhadap Kinerja Keuangan (2) Pengaruh Likuiditas Terhadap Kinerja Keuangan. Populasi dalam penelitian ini adalah seluruh perusahaan perbankan yang terdaftar di Bursa Efek Indonesia tahun 2014-2018 yang berjumlah 25 perusahaan. Teknik pengambilan sampel adalah purposive sampling. Sampel penelitian ini adalah 125 perusahaan. Analisis data dengan regresi berganda.

Hasil penelitian ini menyimpulkan bahwa: (1) Struktur Modal dan Likuiditas tidak berpengaruh signifikan terhadap Kinerja Keuangan (2) Struktur Modal secara parsial berpengaruh signifikan terhadap Kinerja Keuangan (3) Likuiditas secara parsial tidak berpengaruh signifikan terhadap Kinerja Keuangan. Dalam penelitian ini disarankan untuk melakukan penelitian lebih lanjut dengan memasukkan variabel independen lainnya yang diduga memiliki pengaruh terhadap kinerja keuangan agar cakupannya lebih luas dan lebih banyak referensi bagi peneliti lain.
\end{abstract}

\section{Kata Kunci: Struktur Modal, Likuiditas, Kinerja Keuangan}

\begin{abstract}
ABSTRACK
This study aims to obtain empirical evidence about: (1) Effect of Capital Structure on Financial Performance (2) Effect of Liquidity on Financial Performance. The population of this research is all banking companies listed on the Indonesia Stock Exchange in 2014-2018 amounting to 25 companies. The sampling technique is purposive sampling. The sample of this research is 125 companies. Data analysis with multiple regression.

The results of this study concluded that: (1) Capital Structure and Liquidity did not significantly influence Financial Performance (2) Capital Structure partially had a significant effect on Financial Performance (3) Liquidity partially had no significant effect on Financial Performance. In this research it is recommended to conduct further studies by including other independent variables that are suspected to have an influence on financial performance so that the scope is wider and more references to other researchers.
\end{abstract}

Keywords: Capital Structure, Liquidity, Financial Performance

\section{A. PENDAHULUAN}

Sektor perbankan memegang peranan yang sangat penting dalam perekonomian karena bank merupakan lembaga intermediasi yang menghubungkan antara masyarakat yang memiliki kelebihan dana dan masyarakat yang membutuhkan dana, selain itu bank merupakan penunjang sektor riil yang berperan aktif dalam perekonomian Indonesia.
Kemampuan bank dalam menghadapi resiko dan menjalankan kegiatan operasionalnya dapat tercermin dari kinerja keuangannya. Kinerja keuangan dapat dinilai dari beberapa aspek antara lain dapat mengukur kemampuan likuiditas, rentabilitas dan solvabilitas. Bank dalam menjalankan kegiatan operasionalnya perlu didukung oleh struktur modal yang memadai, sehingga bank tersebut dapat melakukan 
diversifikasi usaha yang lebih banyak dan kemungkinan kegagalan dalam menjalankan usaha atau kebangkrutan lebih kecil. Dengan demikian kemampuan positif bank tersebut akan tercermin dari hasil kinerja keuangannya.

Struktur modal merupakan pendanaan kegiatan bank yang terdiri dari kombinasi utang dan modal sendiri yang digunakan oleh bank. Pendapatan yang diperoleh bank dapat ditingkatkan dengan penggunaan struktur modal yang maksimal. Secara teoritis penggunaan utang akan dapat meningkatkan laba dan selanjutnya dapat meningkatkan profitabilitas jika laba yang diperoleh tersebut melebihi beban bunga hutangnya. Sebaliknya jika laba diperoleh dari penggunaan hutang tersebut lebih kecil dari beban bunga hutang maka laba yang diperoleh bank akan menurun dan profitabilitasnyapun dapat menurun. Beberapa rasio yang dapat digunakan Bank dalam mengukur struktur modalnya antara lain Debt Ratiodan Debt to Equity Ratio.Debt Ratio(DR)merupakan rasio utang yang digunakan untuk mengukur seberapa besar asset perusahaan dibiayai oleh utang perusahaan atau menunjukkan seberapa besar proporsi antara kewajiban dengan kekayaan yang dimiliki.Modal utang yang digunakan bank untuk meningkatkan operasional akan berdampak pada peningkatanlaba dari perusahaan sehingga bank dapatmembayarpokok pinjaman,angusran dan bunga. Semakin tinggi debt ratio maka semakin besar jumlah modal pinjaman yang digunakan dalam menghasilkan keuntungan (Syamsuddin, 2016:54).

Pada penelitian terdahulu terdapat beberapa perbedaan hasil mengenai struktur modal, likuiditas dan kinerja keuangan. Pada penelitian Hardianti (2017) struktur modal berpengaruh positif dan signifikan terhadap kinerja keuangan dan likuiditas tidak berpengaruh signifikan terhadap kinerja keuangan
perusahaan.Secara simultan struktur modal dan likuiditas berpengaruh positif dan signifikan terhadap kinerja keuangan. Penelitian Irvan (2014) menunjukkan hasil variabel struktur modal memiliki pengaruh yang signifikan terhadap kinerja keuangan.

Beberapa perbedaan pendapat di atas membuat penulis tertarik untuk melakukan penelitian mengenai struktur modal dan likuiditas terhadap kinerja keuangan. Variabel pengukuran struktur modal yang digunakan oleh penulis adalah Debt to Equity Ratio (DER), variabel likuiditas dihitung dengan Current Ratio (CR). DER merupakan perhitungan rasio yang menunjukkan persentase hutang yang terdapat pada modal. CR adalah rasio yang mengukur persentase kemampuan perusahaan membayar kewajiban jangka pendeknya dengan aset lancar.

\section{B. METODE PENELITIAN}

\section{Rancangan Penelitian}

Metode penelitian ini merupakan penelitian asosiatif kuantitatif. Penelitian kuantitatif yaitu penelitian yang menggunakan data numerik yang diolah menggunakan metode statistika. Berdasarkan tingkat penggunaannya, penelitian ini merupakan penelitian kausal asosiatif. Penelitian kausal asosiatif yaitu penelitian dengan karakteristik maslah berupa sebab-akibat antara dua variabel atau lebih.

\section{Operasionalisasi Variabel}

Variabel adalah suatu sebutan yang dapat diberi nilai angka (kuantitatif) atau nilai-nilai mutu (kualitatif).Dalam penelitian ini yang menjadi variabel independen yaitu struktur modal (X1) dan likuiditas (X2). Sedangkan untuk variabel dependennya adalah kinerja keuangan (Y).

\section{Teknik Pengumpulan Data}

Teknik pengumpulan data yang dilakukan oleh peneliti adalah dokumentasi, berupa laporan keuangan tahunan (annual report) perusahaan 
perbankan yang telah diterbitkan dan telah diaudit oleh akuntan publik yang terdaftar di Bursa Efek Indonesia pada periode 2014 sampai dengan 2018 melalui situs resmi Bursa Efek Indonesia yaitu www.idx.co.id.

\section{Metode Analisis Data}

Menurut "Sugiyono" (2018:243)data terdiri atas dua macam yaitu data kualitatif dan data kuantitatif."

1. Teknik Analisis Data Kualitatif: Dalam penelitian kaulitatif, data diperoleh dari berbagai sumber, dengan menggunakan teknik pengumpulan data yang bermacammacam (triangulasi), dan dilakukan secara terus menerus sampai datanya jenuh.

2. Teknik Analisis Data Kuantitatif: Dalam penelitian kuantitatif, teknik analisis data yang digunakan sudah jelas, yaitu diarahkan untuk menjawab rumusan masalah atau menguji hipotesis yang telah dirumuskan dalam proposal. Karena datanya kuantitatif, maka teknik analisis data menggunakan metode statistik yang sudah tersedia.

Sebelum melakukan pengujian hipotesis, perlu diketahui apakah data yang digunakan telah mencerminkan data yang relevan dan konsisten. Maka hal selanjutnya yang harus dilakukan adalah dengan melakukan uji statistik deskriptif dan uji asumsi klasik yang meliputi uji normalitas, uji heterokedastisitas, multikolinearlitas, dan autokorelasi.

\section{HASIL DAN PEMBAHASAN}

\section{Analisis Struktur Modal dan Likuiditas Berpengaruh Terhadap Kinerja Keuangan}

Hasil yang diperoleh dari perbandingan $f$ hitung dengan $f$ tabel adalah $\mathrm{f}$ hitung $<\mathrm{f}$ tabel $(1,989<3,07)$, sehingga H01 diterima dan Ha1 ditolak. Dengan demikian dapat disimpulkan bahwa struktur modal dan likuditas secara simultan tidak berpengaruh signifikan terhadap kinerja keuangan.

\section{Analisis Struktur Modal Berpengaruh Terhadap Kinerja Keuangan}

Hasil yang diperoleh dari perbandingan $\mathrm{t}$ hitung dengan $\mathrm{t}$ tabel adalah $\mathrm{t}$ hitung $>\mathrm{t}$ tabel $(1,994>1,9796)$, sehingga H01 ditolak dan Ha1 diterima. Dengan demikian dapat disimpulkan bahwa struktur modal secara parsial berpengaruh signifikan terhadap kinerja keuangan.

\section{Analisis Likuiditas Berpengaruh Terhadap Kinerja Keuangan}

Hasil yang diperoleh dari perbandingan $t$ hitung dengan $\mathrm{t}$ tabel adalah $\mathrm{t}$ hitung $<\mathrm{t}$ tabel $(0,542<1,9796)$, sehingga H01 diterima dan Ha1 ditolak. Dengan demikian dapat disimpulkan bahwa likuiditas secara parsial tidak berpengaruh signifikan terhadap kinerja keuangan.

\section{SIMPULAN DAN SARAN}

\section{Simpulan}

Berdasarkan hasil pengujian, diperoleh hasil yaitu

1. Hasil yang diperoleh dari perbandingan $\mathrm{f}$ hitung dengan $\mathrm{f}$ tabel adalah $\mathrm{f}$ hitung < $\mathrm{f}$ tabel $(1,989<$ 3,07), sehingga H01 diterima dan Ha1 ditolak. Dengan demikian dapat disimpulkan bahwa struktur modal dan likuditas secara simultan tidak berpengaruh signifikan terhadap kinerja keuangan.

2. Hasil yang diperoleh dari perbandingan $t$ hitung dengan $t$ tabel adalah $\mathrm{t}$ hitung $>\mathrm{t}$ tabel (1,994>1,9796), sehingga H01 ditolak dan Ha1 diterima. Dengan demikian dapat disimpulkan bahwa struktur modal secara parsial berpengaruh signifikan terhadap kinerja keuangan. 
3. Hasil yang diperoleh dari perbandingan $t$ hitung dengan $t$ tabel adalah $\mathrm{t}$ hitung $<\mathrm{t}$ tabel $(0,542<1,9796)$, sehingga H01 diterima dan Ha1 ditolak. Dengan demikian dapat disimpulkan bahwa likuiditas secara parsial tidak berpengaruh signifikan terhadap kinerja keuangan.

Kemudian pada hasil uji koefisien determinasi yaitu sebesar 0,035 atau $3,5 \%$, artinya pengaruh struktur modal dan likuiditas terhadap kinerja keuangan adalah sebesar $3,5 \%$. Sedangkan sisanya 96,5\% dipengaruhi oleh variabel lain yang tidak disebutkan pada penelitian ini.

\section{Saran}

Berdasarkan hasil penelitian yang telah dilakukan dapat disampaikan beberapa saran yang bisa menjadi masukan untuk penelitian yang akan datang, antara lain:

1. Bagi setiap perusahaan sebaiknya lebih mempertimbangkan faktor likuiditas dan struktur modal yang diduga memiliki pengaruh terhadap kinerja keuangan.

2. Bagi peneliti selanjutnya dengan topik yang sejenis dilakukan untuk melakukan kajian lebih lanjut dengan memasukkan variabel independen lainnya yang diduga memiliki pengaruh terhadap kinerja keuangan supaya cakupannya lebih luas dan lebih memberikan referensi kepada peneliti lainnya.

\section{E. DAFTAR RUJUKAN}

Brealey, Myers, dan Marcus. 2011. Dasar-dasar Manajemen Keuangan Perusahaan. Edisi kelima. Jilid 2. Penerjemah Bob Sabran MM. Jakarta: Penerbit Erlangga.
Brigham, Eugene F. dan Joel F. Houston. 2016. Dasar-Dasar Manajemen Keuangan. Buku 1. Edisi 11. Jakarta : Salemba Empat.

Chris, Sandy Irvan, 2014. Analisis Pengaruh Struktur Modal terhadap Kinerja keuangan pada Perbankan di Indonesia. Bogor: Skripsi Instituti pertanian.

Efendi, Ifin Aria. 2016. Pengaruh Struktur Modal, Profitabilitas, Ukuran Perusahaan, dan Likuiditas Terhadap Nilai Perusahaan. Skripsi. Surakarta: Universitas Muhammadiyah.

Fahmi, Irham. 2017. Analisis Laporan Keuangan. Bandung: Alfabeta

Ghozali, Imam. 2011. Aplikasi Analisis Multivariate Dengan Program IBM SPSS 19. Edisi Kelima. Semarang: Universitas Diponegoro.

Harahap, Sofyan Syafri. 2015. Analisis Kritis atas Laporan Keuangan. Cetakan ke-12. Jakarta: PT Raja Grafindo Pustaka Utama

Hardianti, Dwiputri Aprian, 2017. "PENGARUH STRUKTUR MODAL, LIKUIDITAS, DAN UKURAN PERUSAHAAN TERHADAP KINERJA KEUANGAN PADA PERUSAHAAN

MANUFAKTUR SUBSEKTOR KOSMETIK DAN KEPERTUAN RUMAH TANGGA YANG TERDAFTAR DI BURSA EFEK INDONESIA (BEI) PERIODE 2008-2015”. Skripsi. Lampung: Universitas Lampung. 
Hery 2016, Analisis Laporan keuangan Integrated and Comprehensive edition, Grasindo, Jakarta.

Holiwono, Andreas M. 2016. Pengaruh Struktur Modal Terhadap Kinerja Keuangan Perusahaan Sektor Manufaktur Sub Sektor Makanan dan Minuman yang Terdaftar di BEI (Periode 2010-2014). Skripsi. Fakultas Ekonomi dan Bisnis. Universitas Hasanuddin: Makasar.

Horne, James C. Van dan Wachowicz, John M. 2012. Prinsip-prinsip Manajemen Keuangan. Edisi 13. Buku satu. Penerjemeh Quratul'ain Mubarakah. Jakarta: Selemba Empat.

Husnan, Suad. 2013. Manajemen Keuangan: Teori dan Penerapan Keputusan Jangka Panjang. Edisi keempat. Yogyakarta : BPFE

Kasmir. 2017. Analisis Laporan Keuangan. Cetakan ke-10. Jakarta: PT Rajagrafindo Persada.

Kusumajaya, Dewa Kadek. 2011. Pengaruh Struktur Modal dan Pertumbuhan Perusahaan Terhadap Profitabilitas dan Nilai Perusahaan Pada Perusahaan Manufaktur di Bursa Efek Indonesia. Tesis. Universitas Udayana: Denpasar.

Mahendra, Alfredo. 2011. Pengaruh Kinerja Keuangan Terhadap Nilai Perusahaan. Jurnal. Universitas Udayana Denpasar.

Munawir. 2012. Analisis Laporan Keuangan. Liberty. Yogyakarta.

Siregar, Syofian. 2013, Metode Penelitian Kuantitatif, Penerbit Kencana : Jakart 